\title{
Financial Performance Measures and Business Objectives Attainment in Fast Food SMMEs in the Cape Metropolis: A preliminary Liability and Suitability analysis
}

\author{
Clency Ngary
}

Yolandé Smit

\author{
Juan-Pierré Bruwer
}

Faculty of Business, Cape Peninsula University of Technology, P.O.Box 625, Cape Town, 8000, South Africa, Email: BruwerJP@cput.ac.za

Wilfred I. Ukpere

Department of Industrial Psychology and People Management, Faculty of management, University of Johannesburg, Johannesburg, Gauteng South Africa, Email:wiukpere@uj.ac.za

Doi:10.5901/mjss.2014.v5n20p909

Abstract

According to the Small Business Act No. 102 of 1996, Small Medium and Micro Enterprises (SMMEs) were introduced by the South African government to assist with the achievement of uplifting the national economy to reduce the rising trend unemployment and poverty in the country. SMMEs are believed to contribute up to $30 \%$ of the Gross Domestic Product of South Africa and are further believed to be responsible for absorbing up to $80 \%$ of the national labour force. Regrettably, prior research suggests that these initiatives have not succeeded in reducing unemployment and eradicating poverty, since more than $75 \%$ of SMMEs have been reported to fail within their first two years of existence. Economic factors have been blamed for the dismal outcomes. However, the achievement of business objectives is very relevant to how a business is managed, particularly from a financial outlook. In essence, the current authors are of the view that SMMEs were not attaining their objectives owing to the ineffective utilisation of financial performance measures, which consequently affects the smooth existence of these entities as a going concern. The main objective of this paper was to determine the extent to which SMMEs make use of financial performance measures to attain their business objectives. The research adopted a quantitative approach, which entails the collection of data from 30 SMMEs leaders (owners and/or managers) in the Cape Metropolis. All participants were required to adhere to a list of strict delineation criteria. The finding reveals that SMMEs leaders do make use of financial performance measures to manage their respective businesses towards the attainment of business objectives, but only to a limited extent.

Keywords: SMMEs, Financial performance measures, Business objectives, Fast food industry, South Africa

\section{Introduction}

In South Africa, Small Medium and Micro Enterprises (SMMEs) are formally defined by the Small Business Act No. 102 of 1996: "... as small separate and distinct business entities ... that are owned and/or managed by one or more owner(s), that conduct relevant business in any sector and/or sub-sector of the national economy of South Africa" (South Africa, 1996). Moreover, in the same Act, these entities have been initiated by the South African government as the core objective of uplifting the national economy through means of aiding in (1) decreasing of national unemployment, and (2) the eradication of national poverty. Berry, Blottnitz, Cassim, Kesper, Rajaratnam and Seventer (2002) support the latter sentiment when stating that South African SMMEs fulfil a critical role in the establishment of jobs and the stimulation of national economic growth. These entities generally have large absorption capacities for labour. The absorption capacities of these entities are placed in perspective by Swart (2011) who avers that South African SMMEs are reported to be responsible for employing approximately $80 \%$ of the national labour force. In terms of boosting the national economy, South African SMMEs are also believed to contribute up to $30 \%$ to the national Gross Domestic Product (GDP). Due to the vast amounts of potential that South African SMMEs have, these entities are often regarded to be at the forefront of the economic development, as well as recognised as actively involved in the resolution of socio-economic problems 
(Kesper, 2001).

Prior research studies have suggested that South African SMMEs are not achieving their objectives, as legally imposed on them by national the government due to, among other reasons, the high failure rate of SMMEs (Van Eeden, Venter \& Viviers, 2003; Lighthelm, 2011; Fatoki, 2012). The current dispensation has been pinned on many plausible factors. Cassar (2004) mentioned economic factors as the most plausible factor. Examples of these factors are limited access to funds, lack of real-time business information, lack of business knowledge, lack of business skills, high interest rates, strict government legislation, taxation rates, high inflation rates, volatile market conditions and crime (Bbenkele, 2007; Grundling \& Kaseke, 2010; Fatoki \& Garwe, 2010; Salie, Strauss, Davids, Smit, Boshoff \& Bruwer, 2014). It is understandable that all business entities will be susceptible to changes in the economic environment which are directly influenced by economic factors. However, smaller businesses will be more vulnerable to these changes as opposed to their larger counterparts. This is especially the case since SMMEs do not have sophisticated and durable infrastructures (Siwangaza, Bruwer, Smit \& Ukpere, 2014).

The above sentiment is further supported by Jooste (2008) who is of the opinion that the overall influence of economic factors, on the economic environment in which SMMEs have to operate in, has an adverse influence on these entities' financial performance, particularly in their profitability, liquidity, solvency and efficiency. The financial performance of any business should be appropriately measured, so much so that it will assist business leaders in making informed business decisions in order to enhance the success of that business (Bourne, Neely, Mills \& Platts, 2003). Furthermore, the measurement of financial performance should also aid in the identification of credible strengths, weaknesses, opportunities and threats - culminating in a well-rounded overview of where a business stands in terms of achieving its respective objectives. Du Plooy, Goodey, Lötter, Nortjé and Meyer (2005), in line with the above, stated that the attainment of objectives, particularly in small businesses, can be greatly enhanced by means of (1) making use of financial statements, and (2) making use of ratio analyses to measure financial performance. Financial performance measures used in practice are very formal, since they require a certain level of 'education' to be suitably designed and interpreted. Therefore it is of no surprise that Bruwer (2010) and Ismaila (2011) found that South African SMMEs do not excessively make use of formal financial performance measures. At most, only bank statements are used by some business leaders to make formal business decisions.

\section{Problem Statement}

South African SMMEs are not attaining their respective business objectives due to the ineffective utilisation of financial performance measures, the consequences of which is business failures.

\subsection{Research questions}

The above statement led to the following research questions:

- To what extent do SMME leaders make use of financial performance measures, in order to make effective business decisions?

- What financial performance measures are used by SMME leaders?

- How frequently are these financial performance measures used by SMME leaders?

- How supportive are these financial performance measures to SMMEs leaders in making effective business decisions?

\subsection{Research objectives}

The research objectives of this paper are

- To establish the extent to which SMME leaders make use of financial performance measures in order to make effective business decisions,

- To establish the actual financial performance measures that are utilised by SMMEs,

- To determine how frequently SMME leaders make use of their financial performance measures,

- To ascertain how supportive these financial performance measures are to SMME leaders in making effective business decisions. 


\section{Literature Review}

\subsection{SMMEs in South Africa}

In South Africa, SMMEs were formally introduced by the national government after identifying a need to assist with the growth of the economy through reducing unemployment and alleviating poverty (Mabesele, 2009). Not only are these entities formally defined and protected by the Small Business Act No. 102 of 1996, but these entities are also regarded as vitally important to the economic prosperity of South Africa as they actually serve as defenders in the fortification against economic stagnation (Fatoki \& Garwe, 2010). Kongolo (2010) makes the point that South African SMMEs account for approximately $91 \%$ of all business entities that are currently in operation in South Africa, while Swart (2011) further mentions that South African SMMEs contribute an estimated 30\% to the national GDP; further absorbing an estimated $80 \%$ of the national workforce in the country. From these statistics it is evident that the value that SMMEs adds in South Africa is quite extensive. Maas and Herrington (2007) place this sentiment in perspective when stating that South African SMMEs are perceived to be a 'nursery' for future great companies; an important facet in generating competition, employment and exploit niche markets, both nationally and internationally, all with the purpose to enhance productivity and drive technical change, while stimulating economic development.

As aforementioned, findings from previous researches suggest that these entities do not have a sound history as a going concern. In the early 2000s, Van Eeden, et al. (2003) found that between $70 \%$ and $80 \%$ of all South African SMMEs fail within their first five years of existence. In similar vein Fatoki (2010) describes the failure-rate of South African SMMEs as one of the worst in the world. In a more recent dispensation, research conducted by Lighthelm (2011) and Fatoki (2012) verify that approximately $75 \%$ of South African SMMEs fail within their first two years of operation. As a result Fatoki and Smit (2011) strongly believe that the legally imposed objectives on South African SMMEs can virtually be regarded as 'radical'. In an attempt to measure how well South African SMMEs attain their legally imposed objectives, it is important to evaluate certain economic indicators as follows: Population size: The population size refers to the number of national citizens that were living in South Africa. This statistic can be used to calculate the estimated number of unemployed people in a country; Unemployment rate: The unemployment rate refers to the proportion of the population of the labour force that is unemployed. In essence, this statistic can be used to determine the estimated number of unemployed people in a country; Estimated number of unemployed people: The estimated number of unemployed people is a statistic which is calculated by multiplying the population size with the unemployment rate. Essentially, the calculated statistic reveals the estimated number of South African citizens who were regarded as unemployed over a particular period of time (annually); Gini Index: According to the World Bank (2013) the Gini Index indicates the extent to which income or consumption expenditure diverges from a perfect distribution within household or individual. The Gini-index score can range between 0 (an indication of absolute non-equal distribution of income) and 1 (an indication of absolute equal distribution of income). In essence, this statistic shows how well money is distributed among citizens of a country over a particular period. For each of these economic indicators, the statistics are shown from 2010 to 2013 in Table 1 below.

Table 1: Economic indicators to measure the attainment of legally imposed objectives of South African SMMEs

\begin{tabular}{|l|c|c|c|c|}
\hline Indicator & $\mathbf{2 0 1 0}$ & $\mathbf{2 0 1 1}$ & $\mathbf{2 0 1 2}$ & $\mathbf{2 0 1 3}$ \\
\hline Population size & 49.0 million & 49.3 million & 49.9 million & 50.5 million \\
\hline Unemployment rate & $23.3 \%$ & $24.9 \%$ & $24.4 \%$ & $25.2 \%$ \\
\hline Estimated number of unemployed people & 11.4 million & 12.3 million & 12.2 million & 12.7 million \\
\hline Gini-index & 0.63 & 0.64 & 0.67 & 0.69 \\
\hline
\end{tabular}

Source: Indexmundi (2014)

From the above table it is evident that the unemployment rate (percentage-wise) did not fluctuate extensively from 2010 to 2013. There was however a significant change in the estimated number of unemployed people over the same period, from 2010 to 2011. The estimated number of unemployed people increased by an approximate 900000 people (+ 7.9\%), while between 2011 and 2012, the same statistic decreased by an estimated 100000 people $(-0.8 \%)$. Between 2012 and 2013 however, the number of unemployed people increased by a guesstimated 500000 people $(+4.1 \%)$. In essence, it can be said over the past 4 years the South African population size grew by \pm 1500000 people of which only \pm 200000 were formally employed. As such, it is clear that unemployment is still a severe issue in South Africa. 
Furthermore, with a Gini-index of greater than 0.60 and constantly increasing from 2010 onwards, it is fair to say that poverty in South African became worse, year on year. This is especially the case since a 0.5 Gini-index score represents an absolute 'average' distribution of money within an economy. According to Indexmundi (2014) at least 50\% of South African citizens were living below the poverty line, earning less than R4 900 per year. In fact, the analogy can be drawn that from the 50.5 million South African citizens in 2013 , nearly 25.3 million people were making a living on less than R4 900 per year. In essence, it is obvious that poverty is still a major challenge in South Africa.

\subsection{Economic factors affecting SMMES}

The dismal business continuation statistics of South African SMMEs has attracted a large number of debates as to what spurs it. According to Bruwer (2010), the blame for the high failure-rate of SMMEs is often pinned on economic factors. According to Jessops (2014) economic factors relate to any consideration that can affect the ability of a business entity to generate profit such as the change of cost of commodities, interest rate, exchange rates and rate of inflation, among others. As economic factors encompass a broad spectrum, these factors are generally categorised in terms of macroeconomic factors and micro-economic factors.

Macro-economic factors can be defined as 'external factors', which stem from outside an organisation and which influence a business to a great extent. Furthermore business leaders have little or no control over these factors (Bruwer, 2010). According to Cant and Wiid (2013) macro-economic factors are mostly unpredictable. For this very reason it is crucial that business leaders should be aware of as many external variables in and around their businesses to avoid unpleasant surprises. Also, business leaders need to be able to rapidly adjust to spontaneous opportunities and avert any potential adverse risk that may arise. Among all macro-economic factors, the most prevailing factors that are believed to adversely influence the business continuation of South African SMMEs include: high interest rates, volatile exchange rates, volatile inflation rates, rapid technological advancements, government legislation, fluctuations in the supply and demand of products and service and taxation rates levied on goods and services (Africa Growth Institute, 2013; Grundling \& Kaseke, 2010).

Micro-economic factors, according to Mohr and Fourie (2004) can be defined as internal factors, which originate from inside a business; influencing it to a large extent. Hence, business leaders have some control, at least, over these factors. The most prominent micro-economic factors which are believed to adversely influence the business continuation of South African SMMEs include: the lack of proper marketing strategies, incompetent human resources, the lack of financial resources, insufficient financial knowledge, lack of business infrastructure and inadequate business management skills (Cant \& Wiid, 2013; Africa Growth Institute, 2013; Grundling \& Kaseke, 2010).

Though economic factors are inevitable, it is of great importance that they are managed effectively, efficiency and economically. As mentioned previously economic factors, in addition, have a distinct influence over the overall financial performance of any business. Research conducted by Naudé (2007) and Daniel (2011) show that the most effective way to 'manage' economic factors is to manage the financial performance of a business to such an extent that the financial performance can be sustained or improved upon. To effectively manage the financial performance of a business, financial performance measures are generally used.

\subsection{Financial performance measures}

According to Bruwer and Watkins (2010), the point is made that performance measures should assist business leaders in formulating a better understanding of their respective businesses inside-out. According to Fawcett, Smith and Cooper (1997) performance measures should provide a business leader with a 'bigger picture view' of what exactly is going on in and around his/her business; especially in terms of business processes. Moreover Bourne, et al. (2003) and Rossi (2012) share a similar view in the sense that performance measurement refers to the measurement of both the internal performance and external performance of a business; quantifying what has been achieved in accordance with what should have be achieved. Encapsulating the above, performance measures can therefore be regarded as 'tools', which help business leaders to set and achieve business objectives, and adequately plan on how business processes can be improved to perform better in the foreseeable future (Bourne et al., 2003; Bititci, Nudurupati, Turner \& Creighton, 2002; Naudé, 2007). Moreover, stemming from the above, financial performance measures should provide a representative overview of what is going on in-and-around a business organisation, in terms of its financial performance and allow for evaluations to be made to aid in the making of effective business decisions; sustaining and enhancing its current financial performance (Nieman \& Bennett, 2011). The key financial performance measures that are greatly used in businesses throughout the world are that of financial statements and financial ratios (Bruwer, 2010). These elements are generally 
used to analyse the financial position and financial performance of a business, in depth. Each one of these elements is briefly explained in the proceeding paragraphs.

Financial statements are described by Correia, Flynn, Uliana and Wormald (2012) as financial-tools that are greatly used by business-leaders to evaluate how their business 'performed' in terms of earning a profit (income vs. expenses), being solvent (assets vs. liabilities), being liquid (current assets on hand) and being efficient (net-time taken to earn money). The most common financial statements that are available to business leaders are that of the statement of financial performance (containing income and expenses), the statement of financial position (containing assets, equity and liabilities), the cash flow statement (containing all cash-related items) and the statement of changes in equity (containing a summary of all equity-items). Sowden-Service (2006) expresses the view that financial statements should be compiled to help the users thereof to make adequate business decisions. For instance, prospective investors will use the statements to compile a financial analysis, which will help them to determine whether or not it is worth investing in the business. As such, it is expected that all financial statements should be understandable, relevant, fair, complete and comparable.

Ratio analyses stem from the information contained in the financial statements of a business organisation. Specifically ratio analyses assist the user in analysing and interpreting inter-relationship between various listed items in the financial statements (Du Plooy, et al., 2005). Ratio analyses place emphasis on evaluating the profitability, liquidity, solvency and efficiency of an organisation (Bruwer, 2010).

Hence, it is evident that financial statements and ratio analyses provide a comprehensive overview of how a business performed in a financial manner. Though financial statements and ratio analyses are fairly 'straight-forward' to complete and interpret, these facets are often regarded as 'difficult to understand' by business leaders. This sentiment is confirmed by Jarvis, Curran, Kitching and Lightfoot (2000) who found that SMME leaders generally base their overall evaluation of financial performance solely on cash flow activities (liquidity); using only the bank statement to make relevant business decisions. The problem with only measuring cash flow activities is that, in most cases, SMME leaders tend to mistake a favourable cash flow for a profit. When a business has cash surpluses on hand, this does not necessarily translate to the phenomenon that such a business is profitable (Maseko \& Mayani, 2011). Since most financial performance measures are 'past-oriented', it may not be beneficial to solely make use of liquidity measures to make business decisions. Bruwer (2010) encapsulates the above by raising the point that although most financial performance measures provide historical information, financial statements can be augmented to have a customised and electronic appearance, which is updated accordingly as daily transactions occur, to show real-time information to aid in the making of effective business decisions. Unfortunately majority of SMMEs are believed to be reluctant in utilising financial performance measures.

\section{Research Design and Methodology}

According to Collis and Hussey (2009), the research design of any research study can be classified in accordance with its purpose, process, logic and outcome. This research was a descriptive research. The main intention of the authors was to describe a given phenomenon at hand. This study was quantitative research within the positivistic research paradigm. Quantitative data were gleaned through means of a questionnaire tool. This research also utilised a deductive approach. The initial perceptions of the authors were derived from consulting existing literature. This perception, in turn, was tested through empirical analysis utilising quantitative approach. This study was regarded as basic research as the main intention of the authors was to enhance an understanding of an existing phenomenon.

In terms of the research method, this study adopted a survey method. Data were gleaned from respondents (who had to adhere to a strict set of delineation criteria) through the means of a questionnaire, comprising of mostly closedended questions (Leedy \& Ormrod, 2010). The questionnaire was piloted to (1) academic, and (2) members of the general public, and consisted of 13 questions. These 13 main questions comprised of sub-questions as well. Most questions asked greatly took the form of a 5 point Likert-scale where respondents had to indicate their perception(s), pertaining to certain statement(s), by choosing among the following options: "strongly disagree", "disagree", "neither agree nor disagree", "agree" and "strongly agree".

This study had two distinctive limitations, namely time constraints and monetary constraints. In essence, this research study was conducted over the course of 6 months. Due to financial constraints, the authors decided to confine the study to the Cape Metropolis only. Thus, the chosen sampling method for this study was non-probability sampling namely, purposive sampling. The primary reasons for choosing this particular sampling method, apart from the apparent limitations, were that (1) the size of the population was unknown to the authors, and (2) the authors wanted to obtain rich data on a particular area of focus. Questionnaires were distributed to a total of 30 respondents from where the gleaned 
data were analysed through means of descriptive statistics. All responses received had to come from SMME leaders who had to adhere to a strict set of the delineation criteria in order to justify a valid response:

- All respondents had to be owners and/or managers of their SMMEs.

- All respondents' SMMEs had to adhere to the definition of a SMME according to the National Small Business Act No. 102 of 1996.

- All respondents' SMMEs should have employed between 1 and 100 employees.

- All respondents' SMMEs should have been regarded as non-franchised.

- All respondents' SMMEs should have operated in the fast food industry.

- All respondents' SMMEs should have been in existence (not newly established).

- All respondents' SMMEs should have been situated in the Cape Metropolis (Cape Town CBD and Mowbray).

- All respondents should have been actively involved in their respective SMME's daily business processes.

\subsection{Ethical considerations}

All respondents were assured that all information provided by them would be treated with the highest levels of confidentiality and that they would remain anonymous for the purpose of this study. Furthermore, all respondents were informed of their freedom to withdraw from the study at any point in time they wish. Respondents were also assured that all information provided by them would also purely be used for this research study's purposes.

\section{Data Analysis and Discussion of Findings}

\subsection{General description of respondents}

Respondents were asked a range of identified questions in an attempt to test whether they adhered to the strict set of delineation criteria. As all respondents were operating within the fast food industry, and regarded as non-franchised SMMEs, respondents were asked to provide specifications on the business(es) they owned and/or managed. This is shown in Table 2 below.

Table 2: Frequency table of the particular business which respondents owned and/or managed

\begin{tabular}{|l|c|c|c|c|c|}
\hline \multicolumn{1}{|c|}{ Value Label } & Value & Frequency & Percent & Valid Percent & Cum Percent \\
\hline \hline Restaurant & 1 & 9 & 30.00 & 30.00 & 30.00 \\
Food carts and concession trailers & 2 & 2 & 6.67 & 6.67 & 36.67 \\
Take away stands & 3 & 13 & 43.33 & 43.33 & 80.00 \\
Other & 4 & 6 & 20.00 & 20.00 & 100.00 \\
\hline \hline \multicolumn{2}{|c|}{ Total } & 30 & 100.0 & 100.0 & \\
\hline
\end{tabular}

Source: Authors' Fieldwork (2014)

From the above table, it is evident that majority of respondents were that of restaurants and take away stands (representing $70 \%$ of all respondents). Respondents who elected "other" indicated that they owned and/or managed catering businesses (4 respondents) and sit-down-bakeries ( 2 respondents).

Also, respondents were asked to indicate how many employees they employed in their respective businesses. This is shown in Table 3 below. 
Table 3: Frequency table of the number of employees employed by respondents' owned and/or managed businesses

\begin{tabular}{|c|c|c|c|c|c|}
\hline Value Label & Value & Frequency & Percent & Valid Percent & Cum Percent \\
\hline \hline & 2 & 4 & 13.33 & 13.33 & 13.33 \\
& 3 & 2 & 6.67 & 6.67 & 20.00 \\
& 4 & 3 & 10.00 & 10.00 & 30.00 \\
& 5 & 6 & 20.00 & 20.00 & 50.00 \\
& 6 & 3 & 10.00 & 10.00 & 60.00 \\
& 7 & 3 & 10.00 & 10.00 & 70.00 \\
& 8 & 3 & 10.00 & 10.00 & 80.00 \\
& 9 & 1 & 3.33 & 3.33 & 83.33 \\
& 10 & 2 & 6.67 & 6.67 & 90.00 \\
& 14 & 1 & 3.33 & 3.33 & 93.33 \\
& 24 & 1 & 3.33 & 3.33 & 96.67 \\
& 100 & 1 & 3.33 & 3.33 & 100.00 \\
\hline \hline
\end{tabular}

Source: Authors' Fieldwork (2014)

From the above it is evident that majority of respondents' businesses employed between 2 and 10 people (90\% of respondents' businesses), while three businesses employed between 14 employees and 100 employees. According to the Small Business Act No. 102 of 1996, SMMEs that operate in the fast food industry can be classified, in terms of size, by evaluating the number of employees employed. If a SMME employs between 0 and 5 employees, it is deemed as a 'micro enterprise'; if a SMME employs between 6 and 10 employees, it is deemed as a 'very small enterprise'; if a SMME employs between 11 and 50 employees, it is deemed as a 'small enterprise'; if a SMME employs between 51 and 100 employees, it is deemed as a 'medium enterprise' (South Africa, 1996). Based on the data in Table 3 above, $50 \%$ of respondents owned and/or managed micro enterprises, $40 \%$ of respondents owned and/or managed very small enterprises, and $6.67 \%$ of respondents owned and/or managed small enterprises, while $3.3 \%$ owned and/or managed medium enterprises.

Based solely on the delineation criteria, SMMEs had to operate in the Cape Metropolis, specifically in the Cape Town CBD and Mowbray. When respondents were asked to indicate where their respective SMMEs were based, the following answers were provided in Table 4 below.

Table 4: Frequency table of the location of respondents' owned and/or managed businesses

\begin{tabular}{|c|c|c|c|c|c|}
\hline Value Label & Value & Frequency & Percent & Valid Percent & Cum Percent \\
\hline \hline & Cape Town & 23 & 76.67 & 76.67 & 76.67 \\
& Mowbray & 7 & 23.33 & 23.33 & 100.00 \\
\hline \hline \multicolumn{2}{|c|}{ Total } & 30 & 100.0 & 100.0 & \\
\hline
\end{tabular}

Source: Author's Fieldwork (2014)

Furthermore, respondents were also asked how long their respective businesses have been in existence. In order to fairly represent this statistic, a cross tabulation was done taking into account the number of employees employed and the number of years that respondents' SMMEs have been in existence. This is shown in Table 5 below: 
Table 5: Cross-tabulation of number of employees employed and number of years respondents' SMME have been in existence

\begin{tabular}{|c|c|c|c|c|c|c|c|c|c|c|c|c|c|}
\hline \multirow{2}{*}{$\begin{array}{c}\text { How long has your business been in } \\
\text { existence? (years) }\end{array}$} & \multicolumn{12}{|c|}{ How many employees do you employ? } & \multirow{2}{*}{ Total } \\
\hline & 2 & 3 & 4 & 5 & 6 & 7 & 8 & 9 & 10 & 14 & 24 & 100 & \\
\hline & \multicolumn{4}{|c|}{ Micro } & \multicolumn{5}{|c|}{ Very small } & \multicolumn{2}{|c|}{ Small } & Medium & \\
\hline Less than 1 year (not newly established) & $\begin{array}{l}.00 \\
.00 \%\end{array}$ & $\begin{array}{l}.00 \\
.00 \%\end{array}$ & $\begin{array}{c}1.00 \\
3.33 \%\end{array}$ & $\begin{array}{c}1.00 \\
3.33 \%\end{array}$ & $\begin{array}{l}.00 \\
.00 \%\end{array}$ & $\begin{array}{l}.00 \\
.00 \%\end{array}$ & $\begin{array}{l}.00 \\
.00 \%\end{array}$ & $\begin{array}{l}.00 \\
.00 \%\end{array}$ & $\begin{array}{l}.00 \\
.00 \%\end{array}$ & .00 & .00 & $\begin{array}{l}.00 \\
.00 \%\end{array}$ & $\begin{array}{c}2.00 \\
6.67 \%\end{array}$ \\
\hline 1 year & $\begin{array}{l}.00 \\
.00 \%\end{array}$ & $\begin{array}{c}1.00 \\
3.33 \%\end{array}$ & $\begin{array}{l}.00 \\
.00 \%\end{array}$ & $\begin{array}{l}.00 \\
.00 \%\end{array}$ & $\begin{array}{c}1.00 \\
3.33 \%\end{array}$ & $\begin{array}{l}.00 \\
.00 \%\end{array}$ & $\begin{array}{l}.00 \\
.00 \%\end{array}$ & $\begin{array}{l}.00 \\
.00 \%\end{array}$ & $\begin{array}{l}.00 \\
.00 \%\end{array}$ & .00 & $\begin{array}{l}.00 \\
.00 \%\end{array}$ & $\begin{array}{l}.00 \\
.00 \%\end{array}$ & $\begin{array}{c}2.00 \\
6.67 \%\end{array}$ \\
\hline 2 years & $\begin{array}{c}1.00 \\
3.33 \%\end{array}$ & .00 & $\begin{array}{l}.00 \\
.00 \%\end{array}$ & $\begin{array}{l}.00 \\
.00 \%\end{array}$ & $\begin{array}{l}.00 \\
.00 \%\end{array}$ & $\begin{array}{l}.00 \\
.00 \%\end{array}$ & $\begin{array}{c}2.00 \\
6.67 \%\end{array}$ & $\begin{array}{c}1.00 \\
3.33 \%\end{array}$ & $\begin{array}{r}.00 \\
0.00 \%\end{array}$ & $\begin{array}{l}.00 \\
.00 \%\end{array}$ & $\begin{array}{l}.00 \\
.00 \%\end{array}$ & $\begin{array}{l}.00 \\
.00 \%\end{array}$ & \begin{tabular}{|c|}
4.00 \\
$13.33 \%$
\end{tabular} \\
\hline 3 years & $\begin{array}{c}2.00 \\
6.67 \%\end{array}$ & $\begin{array}{c}1.00 \\
3.33 \%\end{array}$ & $\begin{array}{l}.00 \\
.00 \%\end{array}$ & $\begin{array}{l}.00 \\
.00 \%\end{array}$ & $\begin{array}{l}.00 \\
.00 \%\end{array}$ & $\begin{array}{c}.00 \\
.00 \%\end{array}$ & $\begin{array}{l}.00 \\
.00 \%\end{array}$ & $\begin{array}{l}.00 \\
.00 \%\end{array}$ & $\begin{array}{l}.00 \\
.00 \%\end{array}$ & $\begin{array}{l}.00 \\
.00 \%\end{array}$ & $\begin{array}{c}.00 \\
.00 \%\end{array}$ & $\begin{array}{l}.00 \\
.00 \%\end{array}$ & $\begin{array}{c}3.00 \\
10.00 \%\end{array}$ \\
\hline 4 years & $\begin{array}{c}.00 \\
.00 \%\end{array}$ & $\begin{array}{l}.00 \\
.00 \%\end{array}$ & $\begin{array}{c}.00 \\
.00 \%\end{array}$ & $\begin{array}{c}1.00 \\
3.33 \%\end{array}$ & $\begin{array}{c}1.00 \\
3.33 \%\end{array}$ & $\begin{array}{c}1.00 \\
3.33 \%\end{array}$ & $\begin{array}{l}.00 \\
.00 \%\end{array}$ & $\begin{array}{c}.00 \\
.00 \%\end{array}$ & $\begin{array}{l}.00 \\
.00 \%\end{array}$ & $\begin{array}{c}1.00 \\
3.33 \%\end{array}$ & $\begin{array}{c}.00 \\
0.00 \%\end{array}$ & $\begin{array}{l}.00 \\
.00 \%\end{array}$ & \begin{tabular}{|c|}
4.00 \\
$13.33 \%$ \\
\end{tabular} \\
\hline 5 years & $\begin{array}{c}1.00 \\
3.33 \%\end{array}$ & $\begin{array}{l}.00 \\
.00 \%\end{array}$ & $\begin{array}{l}.00 \\
.00 \%\end{array}$ & $\begin{array}{l}.00 \\
.00 \%\end{array}$ & $\begin{array}{c}1.00 \\
3.33 \%\end{array}$ & $\begin{array}{l}.00 \\
.00 \%\end{array}$ & $\begin{array}{l}.00 \\
.00 \%\end{array}$ & $\begin{array}{l}.00 \\
.00 \%\end{array}$ & $\begin{array}{c}.00 \\
.00 \%\end{array}$ & $\begin{array}{l}.00 \\
.00 \%\end{array}$ & $\begin{array}{l}.00 \\
.00 \%\end{array}$ & $\begin{array}{l}.00 \\
.00 \%\end{array}$ & $\begin{array}{c}2.00 \\
6.67 \% \\
\end{array}$ \\
\hline 6 years & $\begin{array}{l}.00 \\
.00 \%\end{array}$ & $\begin{array}{l}.00 \\
.00 \%\end{array}$ & $\begin{array}{c}1.00 \\
3.33 \%\end{array}$ & $\begin{array}{c}1.00 \\
3.33 \%\end{array}$ & $\begin{array}{l}.00 \\
.00 \%\end{array}$ & $\begin{array}{c}1.00 \\
3.33 \%\end{array}$ & $\begin{array}{l}.00 \\
.00 \%\end{array}$ & $\begin{array}{l}.00 \\
.00 \%\end{array}$ & $\begin{array}{c}1.00 \\
3.33 \%\end{array}$ & $\begin{array}{l}.00 \\
.00 \%\end{array}$ & $\begin{array}{c}.00 \\
.00 \%\end{array}$ & $\begin{array}{l}.00 \\
.00 \%\end{array}$ & $\begin{array}{c}4.00 \\
13.33 \%\end{array}$ \\
\hline 8 years & $\begin{array}{c}.00 \\
.00 \%\end{array}$ & $\begin{array}{l}.00 \\
.00 \%\end{array}$ & $\begin{array}{c}.00 \\
.00 \%\end{array}$ & $\begin{array}{c}1.00 \\
3.33 \%\end{array}$ & $\begin{array}{c}.00 \\
.00 \%\end{array}$ & $\begin{array}{c}1.00 \\
3.33 \%\end{array}$ & $\begin{array}{l}.00 \\
.00 \%\end{array}$ & $\begin{array}{c}.00 \\
.00 \%\end{array}$ & $\begin{array}{c}.00 \\
.00 \%\end{array}$ & $\begin{array}{c}.00 \\
.00 \%\end{array}$ & $\begin{array}{c}.00 \\
.00 \%\end{array}$ & $\begin{array}{c}.00 \\
.00 \%\end{array}$ & $\begin{array}{c}2.00 \\
6.67 \% \\
\end{array}$ \\
\hline 9 years & $\begin{array}{c}.00 \\
.00 \%\end{array}$ & $\begin{array}{c}.00 \\
.00 \%\end{array}$ & $\begin{array}{c}.00 \\
.00 \%\end{array}$ & $\begin{array}{c}.00 \\
.00 \%\end{array}$ & $\begin{array}{c}.00 \\
.00 \%\end{array}$ & $\begin{array}{c}.00 \\
.00 \%\end{array}$ & $\begin{array}{c}1.00 \\
3.33 \%\end{array}$ & $\begin{array}{c}.00 \\
.00 \%\end{array}$ & $\begin{array}{c}1.00 \\
3.33 \%\end{array}$ & .00 & $\begin{array}{c}.00 \\
.00 \%\end{array}$ & $\begin{array}{l}.00 \\
.00 \%\end{array}$ & $\begin{array}{c}2.00 \\
6.67 \%\end{array}$ \\
\hline 13 years & $\begin{array}{l}.00 \\
.00 \%\end{array}$ & $\begin{array}{l}.00 \\
.00 \%\end{array}$ & $\begin{array}{c}1.00 \\
3.33 \%\end{array}$ & $\begin{array}{l}.00 \\
.00 \%\end{array}$ & $\begin{array}{l}.00 \\
.00 \%\end{array}$ & $\begin{array}{l}.00 \\
.00 \%\end{array}$ & $\begin{array}{l}.00 \\
.00 \%\end{array}$ & $\begin{array}{l}.00 \\
.00 \%\end{array}$ & $\begin{array}{c}.00 \\
.00 \%\end{array}$ & $\begin{array}{l}.00 \\
.00 \%\end{array}$ & $\begin{array}{c}.00 \\
.00 \%\end{array}$ & $\begin{array}{l}.00 \\
.00 \%\end{array}$ & $\begin{array}{c}1.00 \\
3.33 \%\end{array}$ \\
\hline 23 years & $\begin{array}{c}.00 \\
.00 \%\end{array}$ & $\begin{array}{c}.00 \\
.00 \%\end{array}$ & $\begin{array}{c}.00 \\
.00 \%\end{array}$ & $\begin{array}{c}1.00 \\
3.33 \%\end{array}$ & $\begin{array}{l}.00 \\
.00 \%\end{array}$ & $\begin{array}{l}.00 \\
.00 \%\end{array}$ & $\begin{array}{l}.00 \\
.00 \%\end{array}$ & $\begin{array}{c}.00 \\
.00 \%\end{array}$ & $\begin{array}{c}.00 \\
.00 \%\end{array}$ & $\begin{array}{l}.00 \\
.00 \%\end{array}$ & $\begin{array}{c}.00 \\
.00 \%\end{array}$ & $\begin{array}{l}.00 \\
.00 \%\end{array}$ & $\begin{array}{c}1.00 \\
3.33 \% \\
\end{array}$ \\
\hline 40 years & $\begin{array}{l}.00 \\
.00 \%\end{array}$ & $\begin{array}{l}.00 \\
.00 \%\end{array}$ & $\begin{array}{l}.00 \\
.00 \%\end{array}$ & $\begin{array}{l}.00 \\
.00 \%\end{array}$ & $\begin{array}{l}.00 \\
.00 \%\end{array}$ & $\begin{array}{l}.00 \\
.00 \%\end{array}$ & $\begin{array}{l}.00 \\
.00 \%\end{array}$ & $\begin{array}{l}.00 \\
.00 \%\end{array}$ & $\begin{array}{c}.00 \\
.00 \%\end{array}$ & $\begin{array}{l}.00 \\
.00 \%\end{array}$ & $\begin{array}{r}1.00 \\
3.33 \%\end{array}$ & \begin{tabular}{|c}
1.00 \\
$3.33 \%$
\end{tabular} & $\begin{array}{c}2.00 \\
6.67 \% \\
\end{array}$ \\
\hline 53 years & $\begin{array}{c}.00 \\
.00 \%\end{array}$ & $\begin{array}{c}.00 \\
.00 \%\end{array}$ & $\begin{array}{c}.00 \\
.00 \%\end{array}$ & $\begin{array}{c}1.00 \\
3.33 \%\end{array}$ & $\begin{array}{l}.00 \\
.00 \%\end{array}$ & $\begin{array}{l}.00 \\
.00 \%\end{array}$ & $\begin{array}{l}.00 \\
.00 \%\end{array}$ & $\begin{array}{c}.00 \\
.00 \%\end{array}$ & $\begin{array}{c}.00 \\
.00 \%\end{array}$ & $\begin{array}{l}.00 \\
.00 \%\end{array}$ & $\begin{array}{c}.00 \\
.00 \%\end{array}$ & $\begin{array}{l}.00 \\
.00 \%\end{array}$ & $\begin{array}{c}1.00 \\
3.33 \%\end{array}$ \\
\hline Total & $\begin{array}{c}4.00 \\
13.33 \%\end{array}$ & $\begin{array}{r}2.00 \\
06.67 \%\end{array}$ & $\begin{array}{c}3.00 \\
10.00 \%\end{array}$ & $\begin{array}{c}6.00 \\
20.00 \%\end{array}$ & $\begin{array}{c}3.00 \\
10.00 \%\end{array}$ & $\begin{array}{c}3.00 \\
10.00 \%\end{array}$ & $\begin{array}{c}3.00 \\
10.00 \%\end{array}$ & $\begin{array}{c}1.00 \\
63.33 \%\end{array}$ & $\begin{array}{r}2.00 \\
06.67 \%\end{array}$ & $\begin{array}{l}1.00 \\
3.33 \%\end{array}$ & $\begin{array}{r}1.00 \\
03.33 \%\end{array}$ & $\begin{array}{c}1.00 \\
3.33 \%\end{array}$ & $\begin{array}{c}30.00 \\
100.00 \%\end{array}$ \\
\hline
\end{tabular}

Source: Author's Fieldwork (2014)

From the above, it clear that 9 micro enterprises, 7 very small enterprises and 1 small enterprise existed for between 0 and 5 years. Furthermore 3 micro enterprises and 5 very small enterprises existed between 6 and 10 years. Also 3 micro enterprises, 1 small enterprise and 1 medium enterprise existed for beyond 10 years.

Respondents were also asked what position they fulfil in their respective SMMEs and for how long they have filled this position in their respective SMME. A cross-tabulation of the position that respondents fulfilled, along with the number of years this position has been filled by them, is evident in Table 6 below.

Table 6: Cross-tabulation of number of the position of respondents in their respective SMMEs, along with their number of years being in this position

\begin{tabular}{|c|c|c|c|c|c|c|c|c|c|c|c|}
\hline \multirow{2}{*}{ What is your position? } & \multicolumn{10}{|c|}{ Duration in position (years) } & \multirow{2}{*}{ Total } \\
\hline & .00 & 1.00 & 2.00 & 3.00 & 4.00 & 5.00 & 6.00 & 7.00 & 8.00 & 12.00 & \\
\hline \multirow[t]{2}{*}{ Owner } & .00 & .00 & 1.00 & .00 & .00 & 1.00 & .00 & .00 & .00 & .00 & 2.00 \\
\hline & $.00 \%$ & $.00 \%$ & $3.33 \%$ & $.00 \%$ & $.00 \%$ & $3.33 \%$ & $.00 \%$ & $.00 \%$ & $.00 \%$ & $.00 \%$ & $6.67 \%$ \\
\hline \multirow[t]{2}{*}{ Manager } & .00 & 4.00 & 5.00 & 3.00 & 1.00 & 2.00 & .00 & 1.00 & .00 & 1.00 & 17.00 \\
\hline & $.00 \%$ & $13.33 \%$ & $16.67 \%$ & $10.00 \%$ & $3.33 \%$ & $6.67 \%$ & $.00 \%$ & $3.33 \%$ & $.00 \%$ & $3.33 \%$ & $56.67 \%$ \\
\hline \multirow[t]{2}{*}{ Owner and manager } & 2.00 & 1.00 & 1.00 & 1.00 & 1.00 & 1.00 & 2.00 & 1.00 & 1.00 & .00 & 11.00 \\
\hline & $6.67 \%$ & $3.33 \%$ & $3.33 \%$ & $3.33 \%$ & $3.33 \%$ & $3.33 \%$ & $6.67 \%$ & $3.33 \%$ & $3.33 \%$ & $.00 \%$ & $36.67 \%$ \\
\hline \multirow[t]{2}{*}{ Total } & 2.00 & 5.00 & 7.00 & 4.00 & 2.00 & 4.00 & 2.00 & 2.00 & 1.00 & 1.00 & 30.00 \\
\hline & $6.67 \%$ & $16.67 \%$ & $23.33 \%$ & $13.33 \%$ & $6.67 \%$ & $13.33 \%$ & $6.67 \%$ & $6.67 \%$ & $3.33 \%$ & $3.33 \%$ & $100.00 \%$ \\
\hline
\end{tabular}

Source: Author's Fieldwork (2014) 
From the above, it is evident that majority of respondents were managers $(56.67 \%)$, while the remaining respondents were either owners (6.67\%) or owner and manager (36.67\%). On average, respondents have filled the role of manager for 3.29 years; the role of owner for 3.5 years; the role of owner and manager for 3.81 years.

\subsection{Use of financial performance measures}

Respondents were asked to indicate which type of financial performance measures they make use of to both track and measure their respective SMMEs' overall financial performances. The latter was done by asking respondents to rate statements on a 5 point Likert-scale which had to be answered by choosing one of the following options every time: $1=$ 'strongly disagree', 2 = 'disagree', 3 = 'neither agree or disagree', 4 = 'agree' and 5 = 'strongly agree'. This is shown in Table 7 below.

Table 7: Frequency distribution table of financial performance measures used by respondents

\begin{tabular}{|c|c|c|c|c|c|c|c|c|c|}
\hline \multirow{2}{*}{\multicolumn{2}{|c|}{ Financial performance measure }} & \multicolumn{5}{|c|}{ Frequencies } & \multirow[b]{2}{*}{ Mean } & \multirow[b]{2}{*}{ St Dev } & \multirow[b]{2}{*}{ Variance } \\
\hline & & Strongly disagree & Disagree & Neither Agree or Disagree & Agree & $\begin{array}{l}\text { Strongly } \\
\text { Agree }\end{array}$ & & & \\
\hline \multirow{11}{*}{ 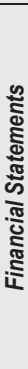 } & Bank statement & 2 & 0 & 2 & 9 & 17 & 4.3 & 1.09 & \multirow{12}{*}{0.34} \\
\hline & Statement of financial position & 6 & 0 & 3 & 6 & 15 & 3.8 & 1.56 & \\
\hline & Cash flow statement & 3 & 1 & 2 & 10 & 14 & 4.03 & 1.27 & \\
\hline & Statement of changes in equity & 12 & 2 & 9 & 1 & 6 & 2.57 & 1.55 & \\
\hline & $\begin{array}{l}\text { Statement of financial } \\
\text { performance }\end{array}$ & 4 & 1 & 4 & 9 & 12 & 3.8 & 1.37 & \\
\hline & Creditor statement & 11 & 3 & 3 & 5 & 8 & 2.87 & 1.7 & \\
\hline & Debtor statement & 10 & 2 & 4 & 5 & 9 & 3.03 & 1.69 & \\
\hline & Trial Balance & 11 & 2 & 4 & 5 & 8 & 2.9 & 1.69 & \\
\hline & Debtors reconciliation statement & 10 & 3 & 8 & 2 & 7 & 2.77 & 1.57 & \\
\hline & Creditors reconciliation statement & 11 & 4 & 7 & 2 & 6 & 2.6 & 1.54 & \\
\hline & Bank reconciliation statement & 8 & 2 & 6 & 2 & 12 & 3.27 & 1.68 & \\
\hline \multicolumn{7}{|c|}{ Mean } & 3.27 & 1.52 & \\
\hline & Direct labour budget & 9 & 1 & 3 & 9 & 8 & 3.2 & 1.63 & \multirow{7}{*}{0.133} \\
\hline s & Inventory budget & 8 & 2 & 3 & 7 & 10 & 3.3 & 1.64 & \\
\hline 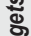 & Cash budget & 5 & 0 & 3 & 6 & 16 & 3.93 & 1.48 & \\
\hline కุ & Sales budget & 6 & 0 & 3 & 8 & 13 & 3.73 & 1.53 & \\
\hline$\infty$ & Cost of sales budget & 5 & 0 & 2 & 11 & 12 & 3.83 & 1.42 & \\
\hline & Overhead budget & 12 & 0 & 5 & 4 & 9 & 2.93 & 1.74 & \\
\hline \multicolumn{7}{|c|}{ Mean } & 3.49 & 1.57 & \\
\hline & Cash receipts journal & 2 & 1 & 1 & 6 & 20 & 4.37 & 1.16 & \multirow{9}{*}{0.416} \\
\hline & Cash payments journal & 3 & 1 & 1 & 5 & 20 & 4.27 & 1.31 & \\
\hline as & General journal & 10 & 1 & 9 & 1 & 9 & 2.93 & 1.64 & \\
\hline$\stackrel{2}{\varpi}$ & Sales journal & 8 & 1 & 2 & 7 & 12 & 3.47 & 1.68 & \\
\hline 흐 & Sales allowance journal & 13 & 3 & 4 & 3 & 7 & 2.6 & 1.67 & \\
\hline ? & Purchases journal & 7 & 1 & 2 & 9 & 11 & 3.53 & 1.59 & \\
\hline & Purchases allowance journal & 11 & 5 & 3 & 3 & 8 & 2.73 & 1.68 & \\
\hline & Petty cash journal & 4 & 1 & 3 & 5 & 17 & 4 & 1.44 & \\
\hline \multicolumn{7}{|c|}{$\frac{1}{M e a n}$} & 3.49 & 1.52 & \\
\hline & Gross profit ratio & 8 & 1 & 1 & 10 & 10 & 3.43 & 1.63 & \multirow{11}{*}{0.07} \\
\hline & Net profit ratio & 8 & 1 & 2 & 8 & 11 & 3.43 & 1.65 & \\
\hline & Return on assets & 12 & 1 & 4 & 5 & 8 & 2.87 & 1.72 & \\
\hline & Return on capital employed & 13 & 1 & 4 & 6 & 6 & 2.7 & 1.66 & \\
\hline$\stackrel{20}{0}$ & Debt collection period & 11 & 1 & 6 & 7 & 5 & 2.8 & 1.56 & \\
\hline 议 & Debt payment period & 10 & 2 & 4 & 7 & 7 & 2.97 & 1.63 & \\
\hline & Current ratio & 12 & 1 & 4 & 6 & 7 & 2.83 & 1.68 & \\
\hline & Quick ratio & 14 & 1 & 5 & 4 & 6 & 2.57 & 1.65 & \\
\hline & Inventory turnover ratio & 12 & 1 & 3 & 8 & 6 & 2.83 & 1.66 & \\
\hline & Debt ratio & 13 & 1 & 3 & 6 & 7 & 2.77 & 1.72 & \\
\hline \multicolumn{7}{|c|}{ Mean } & 2.92 & 1.66 & \\
\hline
\end{tabular}

Source: Authors's Fieldwork (2014)

From the table above it is clear that business leaders perceived performance measures as reasonably important, with journals and budgets regarded as the most important to help in the management of their respective business activities. In terms of the mean of results, journals were rated the most used with an average of 3.49 out of 5 (the most used are the 
cash receipts and cash payments journals), while budgets also scored an average of 3.49 out of 5 (the most used are the cash, sales and cost of sales budgets). In turn, financial statement scored an average of 3.27 out of 5 (most used are the bank and cash flow statements), while ratios scored an average of 2.92 out of 5 (the most used are the gross profit ratio and net profit ratio).

\subsection{Business objective measurement}

Respondents were asked whether they used their respective performance measures (as discussed above) to measure the overall attainment of their business objectives. This was done through the means of asking respondents to respond to statements on a 5 point Likert-scale - 1 = 'strongly disagree', 2 = 'disagree', 3 = 'neither agree or disagree', 4 = 'agree', 5 $=$ 'strongly agree'. This is shown in Table 8 below.

Table 8: Frequency distribution table of how business objectives are being measured by financial performance measures

\begin{tabular}{|c|c|c|c|c|c|c|c|}
\hline Objective measurement & $\begin{array}{l}\text { Strongly } \\
\text { disagree }\end{array}$ & Disagree & Neither Agree or Disagree & Agree & Strongly agree & Mean & St Dev \\
\hline Liquidity (cash on hand) & 2 & 0 & 3 & 9 & 16 & 4.23 & 1.1 \\
\hline Solvency(as little liabilities as possible) & 4 & 1 & 3 & 6 & 16 & 3.97 & 1.43 \\
\hline Efficiency (time-efficient processes ) & 2 & 0 & 2 & 7 & 19 & 4.37 & 1.1 \\
\hline Effectiveness (performing economically ) & 2 & 0 & 4 & 7 & 17 & 4.23 & 1.14 \\
\hline Existence (remaining in operation) & 2 & 0 & 3 & 6 & 19 & 4.33 & 1.12 \\
\hline Profitability (most profit as possible) & 2 & 0 & 2 & 5 & 21 & 4.43 & 1.1 \\
\hline Productivity (dynamic use of resources) & 2 & 0 & 3 & 9 & 16 & 4.23 & 1.1 \\
\hline \multicolumn{7}{|c|}{ Average } & 1.16 \\
\hline
\end{tabular}

Source: Authors' Fieldwork (2014)

From the table above it is clear that business objectives are measured by means of financial performance measures to some extent. With all average means being over 4 , it is evident that respondents mostly agree with the perception that their business objectives can be effectively measured through means of financial performance measures. However, while looking at the average of the standard deviation (which is 1.16) it should be noted again that data vary from the mean, leading to the perception that the agreement among respondents were not really similar to one another.

Respondents were also asked how well their businesses were achieving their respective objectives (in a holistic manner) based on the usage of their financial performance measures. The responses received were as follows in Table 9 below.

Table 9: Frequency distribution table of how well business objectives are being attained according to respondents

\begin{tabular}{|l|c|c|c|c|c|}
\hline \multicolumn{1}{|c|}{ Value Label } & Value & Frequency & Percent & Valid Percent & Cum Percent \\
\hline \hline Neither agree or disagree & 3.00 & 9 & 30.00 & 30.00 & 30.00 \\
Agree & 4.00 & 14 & 46.67 & 46.67 & 76.67 \\
Strongly agree & 5.00 & 7 & 23.33 & 23.33 & 100.00 \\
\hline \hline \multicolumn{2}{|c|}{ Total } & 30 & 100.0 & 100.0 & \\
\hline
\end{tabular}

Source: Authors' Fieldwork (2014)

From the table above it is evident that majority of respondents (70\%) regarded their businesses to be achieving their objectives, while only a minority (30\%) were unsure whether they were achieving their respective business' objectives.

Lastly, respondents were asked how much financial performance measures help them to manage their overall financial performance. Again statements were provided to respondents which had to be answered by using a 5 point Likert-scale - 1 = 'strongly disagree', 2 = 'disagree', 3 = 'neither agree nor disagree', 4 = 'agree', 5 = 'strongly agree'. This is shown in Table 10 below. 
Table 10: Frequency distribution table of financial performance measures (as per Table 7) aided in the management of financial performance of SMMEs

\begin{tabular}{|l|c|c|c|c|c|c|c|}
\hline \multicolumn{1}{|c|}{ Helpfulness of } & Strongly disagree & Disagree & Neither agree or disagree & Agree & Strongly agree & Mean & St Dev \\
\hline Financial statements & 0 & 0 & 7 & 16 & 7 & 4 & 0.69 \\
\hline Budgets & 0 & 1 & 3 & 15 & 11 & 4.2 & 0.76 \\
\hline Journals & 0 & 2 & 7 & 14 & 7 & 3.87 & 0.86 \\
\hline Ratios & 2 & 5 & 7 & 11 & 5 & 3.4 & 1.16 \\
\hline \multicolumn{7}{|c|}{ average } & \\
\hline
\end{tabular}

Source: Authors' Fieldwork (2014)

Stemming from the above table, financial performance measures were perceived to be useful in helping business leaders to attain their business' objectives. With an average mean of 3.87 out of 5 , for all financial performance measures, budgets were regarded the most helpful in attaining business objectives (4.2 out of 5), followed by financial statements (4 out of 5), journals (3.87 out of 5) and ratios (3.4 out of 5). This is an interesting finding as journals and budgets were indicated to be the most frequently used financial performance measures used by respondents, still financial statements were regarded as more helpful in the attainment of business objectives than both journals and budgets. Also, the standard deviation for the first three measures vary between 0.69 to 0.86 , meaning the data obtained were very closely in line with the mean, while for ratios, the deviation was slightly higher.

\section{Conclusion}

In conclusion, it is clearly evident form the data analysed that SMMEs do not make optimum usage of all financial performance measures that are made available to them. Despite journals, budgets, financial statements and ratios being used by respondents, to some extent, to make business decisions, the findings do not validate that financial performance measures actually aid in the attainment of business objectives. Moreover, financial performance measures which were favoured predominantly by respondents seem to be those related to cash, namely cash flows statements, cash receipt journals, cash budgets and bank statements. Hence, the authors are of the opinion that the financial performance measures which are currently being used by respondents can only measure the liquidity aspects of an organisation. This harmonises with the assertion of Maseko and Mayani (2011) that a business can have large cash surpluses while having an asset base that is being depleted by losses. Therefore, based on the research conducted it is clear that SMMEs do in fact make use of financial performance measures in their businesses, but only to a limited extent. Also, the fact that SMMEs do make use of certain financial performance measures does not necessarily signify that they add great value to making better decisions or attaining business objectives despite the statement made by Nieman and Bennett (2011) that an effective analyses of the overall financial performance measures, of any organisation, generally leads to financial success - aiding in the fortification of the business entity's existence. Finally, though SMMEs only make use of financial performance measures to a limited extent, it should also be noted that most these businesses have survived for an extended period of time due to some of the right things they do in terms of measuring and managing their business financial performance and position.

\section{Acknowledgement}

The authors wish to express their sincere gratitude to Suzanne Boshoff and Michelle Davies for their assistance and insight they provided as peer-reviewers during the initial phase of this article.

\section{References}

Africa Growth Institute (2013). South African SMME Business Confidence Index Report.

Bbenkele, E.K. (2007). An Investigation of SMEs Perceptions towards Services Offered by Commercial Banks in South Africa. African Journal of Accounting, Economics, Finance and Banking Research, 1(1): 13-25.

Berry, A., Blottnitz, M., Cassim, R., Kesper, A., Rajaratnam B. \& Seventer, D.E. (2002). The Economics of SMMEs in South Africa. [Online] Available: http://www.tips.org.za/506.pdf [10 January, 2014].

Bititci, U.S., Nudurupati, S. S., Turner, T.J. \& Creighton, S. (2002). Web enabled performance measurement systems: Management implications. International Journal of Operations \&Production Management, 22(11):1273-1287. 
Bourne, M., Neely, A., Mills, J., Platts, K. (2003). Implementing Performance Measurement Systems: A Literature Review. International Journal of Business Performance Management, 5(1):1-24.

Bruwer, J-P. (2010). Sustainability of South African FMCG SMME retail business in the Cape Peninsula. Dissertation submitted in fulfilment of the requirements for the degree Master of Technology: Internal Auditing in the Faculty of Business at the Cape Peninsula University of Technology, Cape Town.

Bruwer, J-P. \& Watkins, A. (2010). The sustainability of fast moving consumer goods retail SMMEs. African Journal of Business Management, 4(16): 3550-3555.

Cant, M.C. \& Wiid, J. (2013). Establishing the Challenges Affecting South African SMEs. International Business \& Economics Research Journal, 12(6): 707-716.

Cassar, G. (2004). The Financing of Business Start Ups. Journal of Business Venturing, 19(1): 191-214.

Collis, J. \& Hussey, R. (2009). Business Research: A Practical Guide for Undergraduate \& Postgraduate Students. New York: Palgrave MacMillan.

Correia, C., Flynn, D., Uliana, E., Wormald, M. (2012). Financial Management. $6^{\text {th }}$ edn Juta and Company Ltd.

Daniel, N.E. (2011). The effective measurement of SME e-commerce performance in the Western Cape. Cape Town October 2011. Dissertation submitted in partial fulfilment of the requirements for the degree Master of Technology: Information Technology in the Faculty of Informatics and Design at the Cape Peninsula University of Technology.

Du Plooy, S., Goodey, H., Lötter, W., Nortjé, D. \& Meyer, C. (2005). X-Kit Undergraduate - Financial Accoutning. Cape Town: Maskew Miller Longman (Pty).

Fatoki. O. (2010). Which New Small and Medium Enterprises in South Africa Have Access of Bank Credit? International Journal of Business and Management. 5(10):128-136.

Fatoki, O. (2012). An Investigation into the Financial Management Practices of New Micro-enterprises in South Africa. Journal of Social Science, 33(2): 179-188.

Fatoki, O. \& Garwe, D. (2010). Obstacles to the growth of new SMEs in South Africa: a principal component analysis approach. African Journal of Business Management, 4(5): 729-738.

Fatoki, O. \& Smit, V.A. (2011). Constraints to credit access by new SMEs in South Africa: A supply-side analysis. African Journal of business Management, 5(4): 1413-1425.

Fawcett, S., Smith, S. \& Cooper, M. (1997). Strategic intent. Measurement, and operational success: making the connection. International Journal of Physical Distribution and Logistics Management, 27(9): 410-421

Grundling, I. \& Kaseke, T. (2010). FinScope South Africa Small Business Survey 2010 [Online]. Avialable from: http://www.finmark.org.za/wp-content/uploads/pubs/FS-Small-Business_-reportFNL1.pdf [Accessed: 06 November 2013]

Inexmundi (2014). South Africa [Online]. Available from: http://www.indexmundi.com/facts/south-africa/gdp [Accessed on 19 February 2014].

Ismaila, B. (2011). Financial performance measurement of manufacturing small and medium enterprises in Pretoria: a multiple exploratory case study. Dissertation submitted in fulfilment of the requirements for the degree Master of Technology: Business Administration, UNISA, Cape Town.

Jarvis, R., Curran, J., Kitching, J., Lightfoot, G., (2000). The use of quantitative and qualitative criteria in the measurement of performance in small firms, Journal of Small Business and Enterprise Development, 7 (2):123-133.

Jessops (2014). Responding to changes in the market environment [Online]. Available: http://businesscasestudies.co.uk/jessops/ responding-to-changes-in-the-market-environment/economic-factors.html\#axzz2uDu8YSHO [Accessed on 25 June 2014].

Jooste, B. (2008). SMEs are feeling the pinch [Online]. Available from: www.iol.co.za/index.php?set_id=13\&art id=vn 20081013054601261 C397975 [Accessed 24 June 2014].

Kesper, A.P. (2001). Making a living in the city - success and failure of small enterprises in the Johannesburg Inner City. Africa Insight, 31(1): 50-58.

Kongolo, M. (2010). Job creation versus job shedding and the roles of SMEs in economic development. African Journal of Business Management, 4(11): 2288-2295.

Leedy, P. \& Ormrod, J. (2010). Practical Research - Planning and Design. New York: Pearson.

Lighthelm, A. (2011). Soweto Businesses Struggling. Available [Online] Available from: http://mg.co.za/article/2011-10-30-sowetos-smallbusinesses-struggle-to-survive [Accessed 24 June 2014].

Maas, G. \& Herrington, M. (2007). Global Entrepreneurship Monitor. South African report 2007 [Online]. Available from: http://www.gemconsortium.org [Accessed: 06 November 2013].

Mabesele, L.A. (2009). The role of performance measures in the fast food franchisee industry to sustain positive growth: Cape Metropole South Africa. Dissertation submitted in fulfilment of the requirements for the degree Master of Technology: Internal Auditing in the Faculty of Business at the Cape Peninsula University of Technology, Cape Town.

Maseko, N. \& Manyani, O. (2011). Accounting practices of SMEs in Zimbabwe: An investigative study of record keeping for performance measurement (A case study of Bindura). Journal of Accounting and Taxation, 3(8):171-181, December.

Mohr, P. \& Fourie, L. (2004). Ekonomie vir Suid-Afrikaanse studente. Pretoria: Van Schaik Publishers.

Naudé, D. (2007). The degree of organisational performance measurement in SMEs, Research Report submitted in the partial fulfilment of the requirements for a Masters degree in Business Leadership, UNISA, Cape Town.

Nieman, G. \& Bennett, A. (2011). Business Management: A value chain approach. $2^{\text {nd }}$ edn. Pretoria: Van Schaik.

Rossi, C.A. (2012). Proposal of a Performance Measurement System for e-commerce SMEs in Denmark. Master Thesis submitted in the 
fulfilment of the requirements for a MSc degree in Business Performance Management, Aarhus University, Austria.

Salie, M., Strauss, N., Davids, M., Smit, Y., Boshoff, S. \& Bruwer, J-P. (2014). The effects of sin tax on the profitability of SMME convenience stores in the Cape Metropole. Topclass Journal of Business Management and Innovation, 1(2): 8-20.

Siwangaza, L. Bruwer, J-P. Smit, Y. \& Ukpere, W. (2014). The Status of Internal Controls in Fast Moving Small Medium and Micro Consumer Goods Enterprises within the Cape Peninsula. Mediterranean Journal of Social Sciences, 5(10): 163-175.

Sowden-Service, C. (2006). Gripping GAAP. Durban: CSS Publishers.

South Africa. (1996). Small Business Act No 102 of 1996, Pretoria Government Printer

Swart, M. (2011). Small businesses are set to lead economic recovery: SMMEs and Economic recovery. South African Institute of Professional Accountants Magazine, pp. 10-12.

Venter, D., Van Eeden, S \& Viviers, S. (2003). A Comparative Study of Selecting Problems Encountered by Small Businesses in the Nelson Mandela, Cape Town and Egoli Metropoles. Journal of South African institute for management statistics, 12(3):13-23. 2003.

World Bank (2013). Gini Index [Online] Available: http://data.worldbank.org/indicator/SI.POV.GINI [Accessed on 24 June 2014]. 